\title{
Pengaruh Pendidikan Kewirausahaan, Efikasi Diri Dan Locus Of Control Terhadap Intensi Berwirausaha
}

\author{
Anastasia Blegur dan Sarwo Edy Handoyo \\ Program Studi Manajemen Fakultas Ekonomi Universitas Tarumanagara, Jakarta \\ Email: anastasiablegur@yahoo.com
}

\begin{abstract}
The purpose of this research is to determine the effect of entrepreneurship education, self-efficacy and locus of control on entrepreneurial intentions of Tarumanagara University Faculty of Economics students. This study uses a non-probability sampling method with the number of samples taken in the study were 150 respondents of the Faculty of Economics students at Tarumanagara University. This questionnaire was distributed to respondents from the Economics department who had taken entrepreneurship courses. Data analysis method uses SEM (Structural Equation Modeling) with the SmartPLS program. The results of this study indicate that there is an influence of entrepreneurship education, self efficacy and locus of control on entrepreneurial intentions of Tarumanagara University Faculty of Economics students.
\end{abstract}

Keywords: Entrepreurial Education, Self Efficacy, and Locus of Control.

Abstrak: Tujuan penelitian ini adalah untuk mengetahui pengaruh pendidikan kewirausahaan, efikasi diri dan locus of control terhadap intensi berwirausaha mahasiswa Fakultas Ekonomi Universitas Tarumanagara. Penelitian ini menggunakan metode pengambilan sampel non-probability sampling dengan jumlah sampel yang diambil dalam penelitian ialah 150 responden mahasiswa Fakultas Ekonomi Universitas Tarumanagara. Kuesioner ini dibagikan kepada responden jurusan Ekonomi yang sudah mengambil mata kuliah kewirausahaan. Metode analisis data menggunakan SEM (Structural Equation Modelling) dengan program SmartPLS. Hasil penelitian ini menunjukan bahwa terdapat pengaruh pendidikan kewirausahaan, efikasi diri dan locus of control terhadap intensi berwirausaha mahasiswa Fakultas Ekonomi Universitas Tarumanagara.

Kata kunci: Pendidikan Kewirausahaan, Efikasi Diri, dan Locus of Control.

\section{LATAR BELAKANG}

Pengangguran dan kemiskinan masih merupakan masalah besar yang dihadapi oleh bangsa Indonesia sekarang ini dan beberapa tahun kedepan. Jika dilihat dari tingkat pendidikan, lulusan Sekolah Menengah Kejuruan atau SMK menyumbang porsi pengangguran terbanyak, yaitu sebesar $8,92 \%$. Jumlah ini diprediksi akan meningkat apabila tidak segera disediakan lapangan kerja baru. Ironisnya angka pengangguran terbanyak justru diciptakan oleh kelompok terdidik. Bertambahnya pengangguran terdidik di Indonesia disebabkan karena para lulusan perguruan tinggi lebih suka menunggu pekerjaan yang mereka rasakan cocok dengan pendidikan mereka dan menolak untuk bekerja dibidang lain, terutama jika bayaran yang ditawarkan dibawah standar yang mereka inginkan (Andika \& 
Madjid, 2012). Berdasarkan dari kondisi tersebut, salah satu alternatif untuk memecahkan masalah pengangguran adalah dengan memberdayakan masyarakat dan kelompok terdidik melalui program kewirausahaan yang diharapkan mampu berkontribusi dalam penyerapan tenaga kerja sehingga mengurangi pengangguran dan beban negara.

(Chimucheka, 2017), menyatakan bahwa salah satu faktor pendorong pertumbuhan kewirausahaan di suatu negara terletak pada peranan universitas melalui penyelenggaraan pendidikan kewirausahaan. Beberapa Fakultas Ekonomi merupakan media dan wadah bagi mereka yang ingin mempelajari bagaimana cara membangun dan menjalankan sebuah usaha, salah satunya adalah dengan diberikannya mata kuliah kewirausahaan. Dimana mereka didorong untuk memunculkan keinginan berwirausaha.

Penelitian (Lorz et al., 2011; Müller, 2011; Pedrini et al., 2017; Zhang et al., 2014) menunjukkan bahwa pendidikan kewirausahaan meningkatkan niat kewirausahaan (entrepreneurial intention), secara umum hasilnya tampaknya bertentangan. Misalnya, dari 41 penelitian yang menilai pengaruh pendidikan kewirausahaan, 33 ditemukan efek positif, enam ditemukan tidak berpengaruh dan dua menemukan hasil negatif (Lorz et al., 2011). Juga dalam tinjauan meta-analitik baru-baru ini, Bae et al. (2014) menemukan bahwa meskipun pendidikan kewirausahaan memiliki efek positif pada intensi berwirausaha, efeknya lemah atau kecil. Dengan demikian, di satu sisi, pendidikan kewirausahaan memiliki efek positif terhadap intensi berwirausaha (Gerba, 2012; Pedrini et al., 2017), di sisi lain, ia memiliki efek negatif (Martin et al., 2012; Oosterbeek et al., 2010) atau tidak ada pengaruh pada intensi berwirausaha (Do Paço et al., 2015).

Seorang wirausaha memerlukan modal, hubungan sosial, dan peluang untuk mencapai keberhasilan usaha, tetapi keyakinan diri atau efikasi diri juga diperlukan dalam melakukan pekerjaannya untuk dapat meraih keberhasilan dalam usaha. Efikasi diri (self efficacy) adalah kepercayaan seseorang atas kemampuan dirinya untuk menyelesaikan suatu pekerjaan (Zulkosky, 2009). Kondisi motivasi seseorang yang lebih didasarkan pada apa yang mereka percaya daripada apa yang secara objektif benar. Persepsi pribadi seperti ini memegang peranan penting dalam pengembangan niat seseorang (Indarti dan Rostiani, 2008).

Penelitian (Ayodele, 2013), yang meneliti niat wirausaha remaja Nigeria menemukan bahwa self efficacy remaja berpengaruh positif terhadap niat berwirausaha. Penelitian Nursito dan Nugroho (2013), self efficacy berpengaruh positif dan signifikan terhadap niat kewirausahaan. Penelitian ini diperkuat oleh penelitian Indarti dan Rostiani (2008), Studi Perbandingan Antara Indonesia, Jepang dan Norwegia. Ditemukan bahwa self efficacy terbukti berpengaruh positif terhadap niat kewirausahaan mahasiswa Indonesia dan Norwegia. Penelitian ini juga menemukan hasil yang bertentangan yaitu, self efficacy tidak berpengaruh signifikan dalam konteks mahasiswa Jepang.

Locus of control menurut Kreitner dan Kinicki dalam (Wiriani et al., 2013), terdiri dari dua konstruk yaitu internal dan eksternal, dimana internal locus of control apabila seseorang meyakini bahwa apa yang terjadi selalu berada dalam kontrolnya dan dia selalu mengambil peran serta bertanggung jawab dalam setiap pengambilan keputusan, sedangkan external locus of control apabila seseorang meyakini bahwa kejadian dalam hidupnya berada diluar kontrolnya.

Penelitian Dinis et al. (2013), mengemukakan bahwa locus of control berpengaruh positif terhadap niat wirausaha siswa sekolah menengah atas. Di dukung juga oleh penelitian Ayodele (2013), menemukan bahwa locus of control berpengaruh positif terhadap niat berwirausaha. Hasil berbeda dari penelitian Bustan (2014), yang menemukan bahwa variabel 
locus of control tidak mempengaruhi niat mahasiswa Politeknik Negeri Sriwijaya untuk berwirausaha.

\section{KAJIAN TEORI}

\section{Entrepreneurial Intention}

Intensi berwirausaha dinyatakan sebagai keinginan dan tekad individu untuk terlibat dalam penciptaan usaha baru (Winkel, 2011). Bansal, et al (2005) mendefinisikan intensi sebagai kemungkinan subyektif individu untuk melakukan suatu perilaku tertentu. Intensi dapat terbentuk ketika seorang individu membuat rencana untuk melakukan suatu perilaku di waktu yang akan datang.

\section{Entrepreneurial Education}

Pendidikan kewirausahaan merupakan usaha sadar yang dilakukan individu untuk menambah wawasan tentang kewirausahaan (Gerba, 2012). Menurut (Alberti et al., 2004), mendefinisikan pendidikan kewirausahaan sebagai transmisi kompetensi kewirausahaan yang terstruktur dan formal yang mengacu pada pemberian keterampilan, konsep dan kesadaran mental individu.

\section{Self Efficacy}

Menurut (Alwisol, 2008), "efikasi diri adalah persepsi diri sendiri mengenai seberapa bagus diri dapat berfungsi dalam situasi tertentu. Efikasi diri berhubungan dengan keyakinan bahwa diri memiliki kemampuan melakukan tindakan yang diharapkan”. Keyakinan dalam diri manusia tergantung dari manusia tersebut, dapat berupa keyakinan untuk melakukan hal baik atau malah melakukan hal buruk.

\section{Locus of Control}

Locus of control menurut Kreitner dan Kinicki dalam (Wiriani et al., 2013), terdiri dari dua konstruk yaitu internal dan eksternal, dimana internal locus of control apabila seseorang meyakini bahwa apa yang terjadi selalu berada dalam kontrolnya dan dia selalu mengambil peran serta bertanggung jawab dalam setiap pengambilan keputusan, sedangkan external locus of control apabila seseorang meyakini bahwa kejadian dalam hidupnya berada diluar kontrolnya.

\section{Kaitan antara Pendidikan Kewirausahaan dan Intensi Berwirausaha}

(Chimucheka, 2017), menyatakan bahwa salah satu faktor pendorong pertumbuhan kewirausahaan di suatu negara terletak pada peranan universitas melalui penyelenggaraan pendidikan kewirausahaan. (Budi et al., 2012) menyebutkan bahwa, "pendidikan kewirausahaan dapat membentuk pola pikir, sikap, dan perilaku pada mahasiswa menjadi seorang wirausahawan (entrepreneur) sejati sehingga mengarahkan mereka untuk memilih berwirausaha sebagai pilihan karir".

Ha1:Terdapat hubungan yang signifikan antara pendidikan kewirausahaan dengan intensi berwirausaha mahasiswa Fakultas Ekonomi Universitas Tarumanagara 


\section{Kaitan antara Efikasi Diri dan Intensi Berwirausaha}

Entrepreneur self efficacy dapat digambarkan sebagai keyakinan pengusaha dalam kemampuannya untuk berhasil dalam situasi atau tugas kewirausahaan tertentu (Drnovšek et al., 2010). Seseorang yang memiliki self efficacy yang tinggi cenderung menunjukkan minat intrinsik perilaku dan aktivitas wirausaha yang lebih tinggi (Boyd dan Vozikis, 1994; Krueger, 2009; Miranda et al., 2017). Selain itu, penilaian efikasi meningkatkan kemungkinan bahwa niat orang-orang selanjutnya akan diterjemahkan ke dalam tindakan (McGee et al., 2009).

Ha2: Terdapat hubungan yang signifikan antara Efikasi Diri dengan intensi berwirausaha mahasiswa Fakultas Ekonomi Universitas Tarumanagara

\section{Kaitan antara locus of control dan Intensi Berwirausaha}

Locus of control adalah ciri kepribadian yang berdampak pada intensi berwirausaha (Hisrich et al., 2008). Locus of control adalah atribut yang menunjukkan rasa kontrol seseorang atas hasil, penghargaan, keberhasilan, atau kegagalan hidup mereka; kata berbeda, itu adalah keyakinan seseorang tentang apa yang mengendalikan hidup mereka (Strauser, 2002).

Ha3: Terdapat hubungan yang signifikan antara locus of control dengan intensi berwirausaha mahasiswa Fakultas Ekonomi Universitas Tarumanagara

Berdasarkan uraian kaitan antar variabel di atas, maka model penelitian yang digunakan dalam penelitian ini adalah sebagai berikut.

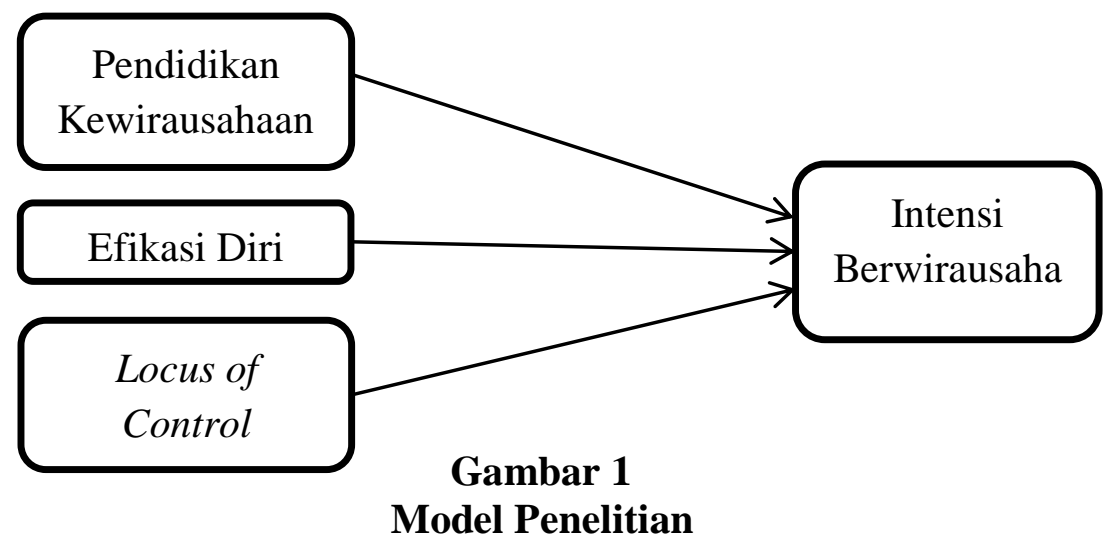

\section{METODOLOGI}

Hasil penelitian ini didapatkan dari pembagian kuesioner kepada mahasiswa Fakultas Ekonomi Universitas Tarumanagara. Penelitian ini berfokus pada minat berwirausaha mahasiswa tersebut. Pemilihan sampel yang dilakukan menggunakan metode purposive sampling. Variabel operasional dalam penelitian ini terdiri dari Pendidikan Kewirausahaan, Efikasi Diri dan Locus of Control yang merupakan variabel independen, Intensi Berwirausaha sebagai variabel dependen.

Berdasarkan data yang didapat dari 150 (100\%) responden, , maka dapat dijelaskan bahwa karakteristik responden berdasarkan jenis kelamin laki-laki terdapat 83 orang $(44,7 \%)$ 
dan jenis kelamin perempuan terdapat 67 orang (55,3\%). Untuk karakteristik berdasarkan yaitu usia 16 - 20 tahun sebanyak 12 orang (8\%), usia 21 - 25 tahun sebanyak 138 orang (92\%), usia 26 - 30 tahun sebanyak 0 orang (0\%). Untuk karakteristik berdasarkan pekerjaan orang tua, mahasiswa yang memilih pekerjaan orang tua adalah berwirausaha sebesar 108 orang $(72 \%)$ dan tidak berwirausaha sebesar 42 orang (28\%). Untuk karakteristik responden berdasarkan jurusan terdapat 93 orang (62\%) adalah jurusan manajemen dan 47 orang (38\%) adalah jurusan akuntansi. Dan untuk karakteristik berdasarkan mahasiswa yang sudah mengambil mata kuliah kewirausahaan, 150 orang menjawab iya (100\%) dan 0 orang menjawab tidak $(0 \%)$.

\section{Hasil Uji Statistik}

Menurut Sekaran and Bogie, 2013:225 Analisis validitas merupakan uji yang dilakukan untuk melihat seberapa tepat sebuah instrumen penelitian dalam penelitian ini adalah kuisioner untuk mengukur suatu konsep yang akan di teliti. Uji validitas dilakukan dengan cara mengukur validitas konvergen, validitas diskriminan dan AVE.

Tabel 1. Hasil Nilai Average Variance Extracted (AVE)

\begin{tabular}{|c|c|}
\hline Variabel & Average Variance Extracted (AVE) \\
\hline Pendidikan Kewirausahaan & $\mathbf{0 . 6 2 3}$ \\
\hline Efikasi Diri & $\mathbf{0 . 6 1 9}$ \\
\hline Locus of Control & $\mathbf{0 . 7 6 6}$ \\
\hline Intensi Berwirausaha & $\mathbf{0 . 6 6 1}$ \\
\hline
\end{tabular}

*Sumber : olahan data Smart-PLS versi 3.00

Menurut Hair et al. (2011) dan Henseler et al. (2009) suatu variabel dapat dikatakan valid apabila memiliki nilai AVE diatas 0.50. Hasil dari AVE menunjukkan nilai sebesar 0.623 untuk variabel pendidikan kewirausahaan, 0,619 untuk variabel efikasi diri, 0.766 untuk variabel locus of control, dan 0.661 untuk variabel intensi berwirausaha. Selanjutnya, suatu indikator dinyatakan valid jika mempunyai nilai loading factor diatas 0,70 terhadap konstruk yang dituju.

Tabel 2. Hasil Nilai Loading Factor

\begin{tabular}{|c|l|c|}
\hline \multicolumn{2}{|c|}{ Indikator } & $\begin{array}{c}\text { Loading } \\
\text { Factor }\end{array}$ \\
\hline PK1 & $\begin{array}{l}\text { Pendidikan kewirausahaan memungkinkan saya mengenali } \\
\text { alternatif pilihan karir. }\end{array}$ & 0.725 \\
\hline PK2 & $\begin{array}{l}\text { Melalui pendidikan kewirausahaan, saya belajar metode untuk } \\
\text { menghasilkan dasar ide bisnis. }\end{array}$ & 0.767 \\
\hline PK3 & $\begin{array}{l}\text { Pendidikan kewirausahaan meningkatkan kemampuan saya untuk } \\
\text { lebih memahami peluang bisnis di lingkungan saya. }\end{array}$ & 0.750 \\
\hline
\end{tabular}




\begin{tabular}{|c|c|c|}
\hline PK4 & $\begin{array}{l}\text { Pendidikan kewirausahaan membantu saya untuk memecahkan } \\
\text { masalah ekonomi dan sosial di lingkungan saya dengan imbalan } \\
\text { bayaran. }\end{array}$ & 0.866 \\
\hline PK5 & $\begin{array}{l}\text { Pendidikan kewirausahaan telah meningkatkan pemahaman saya } \\
\text { dari berbagai sumber dalam memperoleh dana untuk memulai } \\
\text { bisnis baru. }\end{array}$ & 0.870 \\
\hline PK6 & $\begin{array}{l}\text { Saya telah memperoleh kemampuan, pengetahuan, dan kompetensi } \\
\text { yang dibutuhkan untuk mendirikan, mengembangkan, dan } \\
\text { mengelola bisnis baru dari pendidikan kewirausahaan. }\end{array}$ & 0.880 \\
\hline PK7 & $\begin{array}{l}\text { Pelatihan kewirausahaan meningkatkan kesadaran saya mengenai } \\
\text { hak dan tugas seorang wirausaha dan komitmen mereka terhadap } \\
\text { pemangku kepentingan (stakeholders). }\end{array}$ & 0.776 \\
\hline PK8 & $\begin{array}{l}\text { Pendidikan kewirausahaan memungkinkan saya untuk } \\
\text { mengidentifikasi karakteristik seorang pengusaha yang sukses } \\
\text { (seperti pengambilan risiko, proaktif, inovatif, dll). }\end{array}$ & 0.743 \\
\hline PK9 & $\begin{array}{l}\text { Pendidikan kewirausahaan meningkatkan kesadaran saya mengenai } \\
\text { berbagai bentuk bisnis yang dapat saya atur (seperti kepemilikan } \\
\text { tunggal, kemitraan, dll). }\end{array}$ & 0.779 \\
\hline PK10 & Pendidikan kewirausahaan memberi saya perasaan mandiri. & 0.717 \\
\hline ED1 & $\begin{array}{l}\text { Memulai sebuah perusahaan dan membuat perusahaan tetap } \\
\text { berjalan akan mudah bagi saya. }\end{array}$ & 0.732 \\
\hline ED2 & Saya siap untuk memulai perusahaan yang layak. & 0.816 \\
\hline ED3 & Saya dapat mengontrol proses pendirian perusahaan baru. & 0.758 \\
\hline ED4 & $\begin{array}{l}\text { Saya tahu detail praktis yang diperlukan untuk memulai sebuah } \\
\text { perusahaan. }\end{array}$ & 0.819 \\
\hline ED5 & Saya tahu bagaimana mengembangkan proyek kewirausahaan. & 0.806 \\
\hline LC1 & $\begin{array}{l}\text { Keberhasilan saya tergantung pada apakah saya cukup beruntung } \\
\text { untuk berada di tempat yang tepat pada waktu yang tepat. }\end{array}$ & 0.930 \\
\hline LC2 & $\begin{array}{l}\text { Sebagian besar hidup saya dikendalikan oleh kejadian yang tidak } \\
\text { disengaja. }\end{array}$ & 0.930 \\
\hline LC3 & $\begin{array}{l}\text { Ketika saya mendapatkan apa yang saya inginkan, biasanya karena } \\
\text { saya beruntung. }\end{array}$ & 0.906 \\
\hline LC4 & Hidup saya ditentukan oleh tindakan saya sendiri. & 0.748 \\
\hline
\end{tabular}




\begin{tabular}{|c|c|c|}
\hline LC5 & $\begin{array}{l}\text { Ketika saya mendapatkan apa yang saya inginkan, biasanya karena } \\
\text { saya bekerja keras untuk itu. }\end{array}$ & 0.935 \\
\hline LC6 & $\begin{array}{l}\text { Tidak bijaksana bagiku untuk merencanakan terlalu jauh ke depan, } \\
\text { karena akan berdampak buruk apabila hal-hal tersebut berubah. }\end{array}$ & 0.899 \\
\hline LC7 & $\begin{array}{l}\text { Apakah saya sukses atau tidak dalam hidup sebagian besar } \\
\text { tergantung pada kemampuan saya. }\end{array}$ & 0.904 \\
\hline LC8 & $\begin{array}{l}\text { Saya merasa bahwa apa yang terjadi dalam hidup saya sebagian } \\
\text { besar ditentukan oleh orang-orang di posisi yang kuat. }\end{array}$ & 0.751 \\
\hline LC9 & Saya merasa mengendalikan hidup saya. & 0.934 \\
\hline LC10 & Sukses dalam bisnis sebagian besar adalah masalah keberuntungan. & 0.781 \\
\hline IB1 & Tujuan profesional saya adalah menjadi pengusaha. & 0.801 \\
\hline IB2 & Ketika peluang muncul, saya akan menjadi pengusaha. & 0.730 \\
\hline IB3 & Saya siap melakukan apa saja untuk menjadi wirausaha. & 0.831 \\
\hline IB4 & Saya bertekad untuk membangun perusahaan di masa depan. & 0.886 \\
\hline IB5 & $\begin{array}{l}\text { Saya akan melakukan segala upaya untuk memulai dan } \\
\text { menjalankan perusahaan saya sendiri. }\end{array}$ & 0.810 \\
\hline
\end{tabular}

*Sumber : olahan data Smart-PLS versi 3.00

Berdasarkan hasil dari Tabel 2, telah menunjukkan bahwa seluruh indikator memiliki nilai loading factor di atas 0,60 di mana telah memenuhi syarat convergent validity (Hair et al., 2011), sehingga dapat disimpulkan bahwa semua variabel yang ada dalam penelitian ini dapat digunakan.

Tabel 3. Hasil Pengujian Reliabilitas

\begin{tabular}{|c|c|c|}
\hline Variabel & Cronbach's Alpha & Composite Reliability \\
\hline $\begin{array}{c}\text { Pendidikan } \\
\text { Kewirausahaan }\end{array}$ & $\mathbf{0 . 9 3 2}$ & $\mathbf{0 . 9 4 3}$ \\
\hline Efikasi Diri & $\mathbf{0 . 8 4 6}$ & $\mathbf{0 . 8 9 0}$ \\
\hline Locus of Control & $\mathbf{0 . 9 6 5}$ & $\mathbf{0 . 9 7 0}$ \\
\hline Intensi Berwirausaha & $\mathbf{0 . 8 7 1}$ & $\mathbf{0 . 9 0 7}$ \\
\hline
\end{tabular}

*Sumber : olahan data Smart-PLS versi 3.00

Berdasarkan hasil pengujian reliabilitas pada tabel 3, diketahui bahwa variabel di atas memiliki nilai cronbach's alpha dan composite realibility di atas 0,70 . Dengan nilai tersebut, maka dapat disimpulkan bawa data pada penelitian ini reliabel karena memenuhi kriteria dengan hasil yang berada di atas 0,70 (Hair et al., 2011).

Setelah pengujian outer model (validitas dan reliabilitas), pengolahan data variabelvariabel penelitian dilanjutkan pada tahapan pengujian inner model (model struktural) untuk dapat mengetahui kontribusi dari variabel-variabel independen (X) terhadap variabel- 
variabel

dependen (Y). Kriteria pengujian model struktural yang harus dipenuhi pada penelitian ini yaitu nilai koefisien determinasi $\left(\mathrm{R}^{2}\right)$ dan path coefficients.

Hasil nilai koefisen determinasi $\left(\mathrm{R}^{2}\right)$ pada penelitian ini adalah sebesar 0,711 Artinya adalah, variasi perubahan variabel dependen sebesar $71,1 \%$ dapat dijelaskan oleh variabel independen. Sedangkan 28,9\% dijelaskan oleh variabel diluar penelitian ini. Berdasarkan kriteria nilai R-Square yang dikemukakan Sarstedt, Ringle, \& Hair, (2017), pengujian koefisien determinasi mempunyai 3 kriteria yang diantaranya adalah jika nilai R Square 0,25 maka dikategorikan lemah. Jika nilai R Square 0,50 maka dapat dikategorikan sedang dan apabila nilai R Square 0,75 maka dapat dikategorikan kuat.

Tabel 3. Hasil Bootsrapping

\begin{tabular}{|l|c|c|c|c|c|}
\hline & $\begin{array}{c}\text { Original } \\
\text { Sample } \\
(O)\end{array}$ & $\begin{array}{c}\text { Sample } \\
\text { Mean } \\
(M)\end{array}$ & $\begin{array}{c}\text { Standard } \\
\text { Deviation } \\
(\text { STDEV })\end{array}$ & $\begin{array}{c}\text { T-Statistic } \\
(\mid \text { OSTDEV } \mid)\end{array}$ & P-Value \\
\hline $\begin{array}{l}\text { Pendidikan } \\
\text { Kewirausahaan } \rightarrow \\
\text { Intensi Berwirausaha }\end{array}$ & $\mathbf{0 . 3 2 0}$ & $\mathbf{0 . 3 2 9}$ & $\mathbf{0 . 0 9 5}$ & $\mathbf{3 . 3 9 0}$ & $\mathbf{0 . 0 0 1}$ \\
\hline $\begin{array}{l}\text { Efikasi Diri } \rightarrow \text { Intensi } \\
\text { Berwirausaha }\end{array}$ & $\mathbf{0 . 3 1 4}$ & $\mathbf{0 . 3 0 6}$ & $\mathbf{0 . 0 8 2}$ & $\mathbf{3 . 8 1 9}$ & $\mathbf{0 . 0 0 0}$ \\
\hline $\begin{array}{l}\text { Locus of Control } \rightarrow \\
\text { Intensi Berwirausaha }\end{array}$ & $\mathbf{0 . 3 2 9}$ & $\mathbf{0 . 3 3 0}$ & $\mathbf{0 . 0 6 5}$ & $\mathbf{5 . 0 5 4}$ & $\mathbf{0 . 0 0 0}$ \\
\hline
\end{tabular}

*Sumber : olahan data Smart-PLS versi 3.00

\section{DISKUSI}

a. Berdasarkan hasil pengujian yang telah dilakukan pada setiap variabel, variabel X1 (pendidikan kewirausahaan) terhadap Y (intensi berwirausaha) memiliki nilai $t$-statistics sebesar 3,390 dan $P$ values sebesar 0,001. Dari penjelasan diatas, maka dapat disimpulkan bahwa pendidikan kewirausahaan memiliki pengaruh yang positif dan signifikan terhadap Intensi Berwirausaha. Hasil dari penelitian ini menjabarkan penelitian dari (Lorz et al., 2011; Müller, 2011; Pedrini et al., 2017; Zhang et al., 2014) yang menunjukkan bahwa pendidikan kewirausahaan meningkatkan niat kewirausahaan (entrepreneurial intention), secara umum hasilnya tampaknya bertentangan. Misalnya, dari 41 penelitian yang menilai pengaruh pendidikan kewirausahaan, 33 ditemukan efek positif, enam ditemukan tidak berpengaruh dan dua menemukan hasil negatif (Lorz et al., 2011).

b. Berdasarkan hasil pengujian yang telah dilakukan pada setiap variabel, variabel X2 (efikasi diri) terhadap Y (intensi berwirausaha) memiliki nilai $t$-statistics sebesar 3.819 dan $P$ values sebesar 0,000 Dari penjelasan di atas, maka dapat disimpulkan bahwa efikasi diri memiliki pengaruh yang positif dan signifikan terhadap intensi berwirausaha. Hasil penelitian ini sama dengan penelitian (Ayodele, 2013), yang meneliti niat 
wirausaha remaja Nigeria dan menemukan bahwa self efficacy remaja berpengaruh positif terhadap niat berwirausaha.

c. Berdasarkan hasil pengujian yang telah dilakukan pada setiap variabel, variabel X3 (locus of control) terhadap Y (intensi berwirausaha) memiliki nilai $t$-statistics sebesar 5,054 dan $P$ values sebesar 0,000 Dari penjelasan di atas, maka dapat disimpulkan bahwa locus of control memiliki pengaruh yang positif dan signifikan terhadap intensi berwirausaha. Hasil penelitian ini sama dengan penelitian yang dilakukan Ayodele (2013), yang menemukan bahwa variabel locus of control berpengaruh positif terhadap niat berwirausaha. Didukung oleh penelitian dari Uddin dan Bose (2012), yang menemukan adanya pengaruh positif locus of control terhadap niat berwirausaha.

\section{PENUTUP}

Berdasarkan hasil penelitian dari pengujian data dalam penelitian ini menunjukkan bahwa pendidikan kewirausahaan, efikasi diri dan locus of control mempunyai hubungan yang positif dan signifikan terhadap intensi berwirausaha Mahasiswa Fakultas Ekonomi Universitas Tarumanagara. Hal ini dapat terjadi karena pendidikan kewirausahaan, efikasi diri dan locus of control merupakan komponen yang cukup penting dan dapat menciptakan niat berwirausaha bagi mahasiswa Fakultas Ekonomi Universitas Tarumanagara.

Berdasarkan hasil dan keterbatasan di atas, maka saran yang dapat diberikan untuk penelitian selanjutnya, yaitu dengan menggunakan jumlah sampel yang lebih banyak, agar hasil yang didapat lebih akurat dan dapat melengkapi serta memperkuat penelitian-penelitian sebelumnya. Penelitian selanjutnya juga dapat menambah variabel dalam penelitian ini dengan variabel lainnya.

\section{DAFTAR PUSTAKA}

Alberti F, Sciascia dan Poli. 2004. Entrepreneurship Education: Notes on an Ongoing Debate. Disampaikan pada Proceedings of the 14th Annual International Entrepreneurship Conference, University of Nopoli, Federico II, Italy, 4-7 Juli 2004 . Alwisol. (2008). Psikologi Kepribadian (U. Press, ed.). Malang.

Andika, M., \& Madjid, I. (2012). analisis pengaruh sikap, norma subyektif dan efikasi diri terhadap intensi berwirausaha pada mahasiswa fakultas ekonomi universitas syiah kuala (Studi Pada Mahasiswa Fakutas Ekonomi Universitas Syiah Kuala). EcoEntrepreneurship Seminar \& Call for Paper "Improving Performance by Improving Environment," 190-197.

Ayodele, K. O. (2013). Demographics, Entrepreneurial Self-Efficacy and Locus of Control as Determinants of Adolescents' Entrepreneurial Intention in Ogun State, Nigeria. European Journal of Business and Social Sciencesournal of Business and Social Sciences, 1(12), 59-67.

Bae, T. J., Qian, S., Miao, C., \& Fiet, J. O. (2014). The Relationship Between Entrepreneurship Education and Entrepreneurial Intentions: A Meta-Analytic Review. Entrepreneurship: Theory and Practice, 38(2), 217-254.

Bansal, H. S., Taylor, S. F., \& James, Y. S. (2005). "Migrating" to new service providers: Toward a unifying framework of consumers' switching behaviors. Journal of the Academy of Marketing Science, 33(1), 96-115. 
Budi, R., Dan, L., Wijaya, T., \& Mdp, S. (2012). Faktor demografis (gender, latar belakang pendidikan orang tua, dan pengalaman bekerja) dapat mempengaruhi pilihan karir menjadiwirausahawan. Faktor Demografis (Gender, Latar Belakang Pendidikan Orang Tua, Dan Pengalaman Bekerja) Dapat Mempengaruhi Pilihan Karir Menjadiwirausahawan., 1(2), 112-119.

Bustan, J. (2014). Pengaruh Prestasi , Locus of Control , Resiko , Toleransi Ambiguitas , Percaya Diri , Dan Inovasi Terhadap. Jurnal Orasi Bisnis, 11, 60-67..

Chimucheka, Tendai. 2013. The Impact of Entrepreneurship Education on the Establishment and Survival of Small, Micro and Medium Enterprises (SMMEs). Journal Economics, 4(2): 157-168.

Dinis, A., Paço, A. do, Ferreira, J., Raposo, M., \& Rodrigues, R. G. (2013). Psychological characteristics and entrepreneurial intentions among secondary students. Education and Training, 55(8-9), 763-780.

do Paço, A., Ferreira, J. M., Raposo, M., Rodrigues, R. G., \& Dinis, A. (2013). Entrepreneurial intentions: is education enough? International Entrepreneurship and Management Journal, 11(1), 57-75.

Drnovšek, M., Wincent, J., \& Cardon, M. S. (2010). Entrepreneurial self-efficacy and business start-up: Developing a multi-dimensional definition. International Journal of Entrepreneurial Behaviour and Research, 16(4), 329-348.

Fatoki, O. (2014). The Entrepreneurial Intention of Undergraduate Students in South Africa: The Influences of Entrepreneurship Education and Previous Work Experience. Mediterranean Journal of Social Sciences, 5(7), 294-299.

Gerba, Dugassa Tessema. 2012. Impact of entrepreneurship education on entrepreneurial intentions of business and engineering students in Ethiopia. Journal of Economic and Management Studies, 3(2): 258-277.

Hair, J. F., Ringle, C. M., \& Sarstedt, M. (2011). PLS-SEM: Indeed a Silver Bullet. Journal of Marketing Theory and Practice, 19(2), 139-152.

Henseler, J., Ringle, C. M., \&amp; Sinkovics, R. R. (2009). The use of partial least square path modeling in International Marketing. Advances in International Marketing, 20, 277-319.

Hisrich, R. D, Peters, M. P ., \& Shepherd, D. A. (2008). Enterpreneurship: Mc Graw hill International edition.

Indarti, N., \& Rostiani, R. (2008). Undergraduate student's entrepreneurial intention: A comparative study among Indonesia, Japan and Norway. Journal of Indonesian Economy and Business, 23(4), 369-384.

Lorz, M. (2013). The Impact of Entrepreneurship Education on Entrepreneurial Attitudes and Intention. Journal of Small Business Management, 53(1), 75-93.

Martin, B. C., McNally, J. J., \& Kay, M. J. (2013). Examining the formation of human capital in entrepreneurship: A meta-analysis of entrepreneurship education outcomes. Journal of Business Venturing, 28(2), 211-224.

Mueller, S. (2011). Increasing entrepreneurial intention: effective entrepreneurship course characteristics. International Journal of Entrepreneurship and Small Business, 13(1), 55.

Nursito, S., \& Nugroho, A. J. S. (2013). Analisis Pengaruh Interaksi Pengetahuan Kewirausahaan dan Efikasi Diri Terhadap Intensi Wirausaha. Kiat Bisnis, 5(3), 148158.

Oosterbeek, H., van Praag, M., \& Ijsselstein, A. (2010). The impact of entrepreneurship 
education on entrepreneurship skills and motivation. European Economic Review, 54(3), 442-454.

Pedrini, M., Langella, V., \& Molteni, M. (2017). Do entrepreneurial education programs impact the antecedents of entrepreneurial intention?: An analysis of an entrepreneurship MBA in Ghana. Journal of Enterprising Communities.

Sekaran, U., \& Bogie, R. (2013). Research Methods for Business. United Kingdom: Jhon Wiley\&Sons Ltd.

Wiriani, W., Piatrini, P. S., Ardana, K., \& Juliarsa, G. (2013). Efek Moderasi Locus of Control pada Hubungan Pelatihan dan Kinerja pada Bank Perkrediatan Rakyat. Jurnal Ilmiah Akuntansi Dan Bisnis, 8(2), 99-105.

Zhang, Y., Duysters, G., \& Cloodt, M. (2014). The role of entrepreneurship education as a predictor of university students' entrepreneurial intention. International Entrepreneurship and Management Journal, 10(3), 623-641.

Zulkosky, K. (2009). Self-Efficacy: A Concept Analysis. 